\title{
Pertumbuhan dan Produksi Jamur Lentinus sajor-caju isolat LSC9 pada Media Serbuk Gergajian Kayu Sengon (Paraserianthes falcataria) dan Tandan Kosong Kelapa Sawit
}

\author{
The Growth and Production of Lentinus sajor-caju LSC9 Isolate \\ Mushroom on Sengon Sawdust (Paraserianthes falcataria) and \\ Oil Palm Empty Fruit Bunch
}

\author{
HENNY SULISTIANY, LISDAR IDWAN SUDIRMAN* \\ Departemen Biologi, Fakultas Matematika dan Ilmu Pengetahuan Alam, \\ Institut Pertanian Bogor, Dramaga IPB, Bogor, Jawa Barat, 16680 Indonesia \\ Diterima 13 Februari 2015/Disetujui 30 Maret 2015
}

\begin{abstract}
Paraserianthes falcataria sawdust (SGS) and oil palm empty fruit bunch (TKKS) are by-product of forestry and oil palm industries. SGS is commonly substrates for mushroom cultivation. TKKS is expected to be an alternative substrates for mushroom cultivation besides SGS. This study was conducted to determine the growth and fruiting body production of Lentinus sajor-caju LSC9 isolate on SGS, TKKS and mixtures of both substrates (C) with proportion 1:1 respectively. Each substrates were added with $15 \%$ rice bran, $1.5 \%$ gypsum and $1.5 \% \mathrm{CaCO}_{3}$ with a total weight of $500 \mathrm{~g} / \mathrm{bag}$. The result showed that the growth and fruiting body production of Lentinus sajor-caju LSC9 isolate on SGS was better than TKKS and C substrates with biological efficiency on SGS substrates $(\mathbf{5 0 . 8 8 \% )}$ higher than TKKS substrates $(34.42 \%)$ and $C$ substrates $(29.51 \%)$, with vegetative phase (16 days), generative phase (100 days) and growth and development phase (115 days) on TKKS substrates were shorter than SGS and C substrates. The greatest pileus number found on SGS substrates (12 pieces), while the largest pileus diameter found on C substrates $(10.17 \mathrm{~cm})$. Nevertheless, TKKS can be used as alternative substrates for fruiting body production of Lentinus sajor-caju LSC9 isolate.
\end{abstract}

Key words: Lentinus sajor-caju LSC9 isolate, oil palm empty fruit bunch, Paraserianthes falcataria, growth, production

\section{PENDAHULUAN}

Lentinus merupakan jamur pelapuk kayu kelas Basidiomycetes, ordo Polyporales, famili Lentinaceae yang memiliki tubuh buah makroskopis dengan struktur liat, kokoh dan tahan lama (Sudirman 2005). Sebagian besar jenisnya dapat dimakan kecuali yang memiliki tekstur yang keras (Karunarathna et al. 2011). Beberapa jenis jamur ini telah dikonsumsi oleh masyarakat di berbagai negara seperti $L$. subnudus di Nigeria Selatan (Gbolagade et al. 2006), L. squarrosulus di Nigeria (Okhuoya et al. 2010), L. lepideus di China, Jepang dan Korea (Yoon et al. 2011), L. tuberregium di Tamil Nadu, India Selatan (Kumar \& Kaviyarasan 2012) dan L. polychrous Lev. di Thailand dan Laos (Rattanamalee \& Rattanamalee 2012), sedangkan jenis yang dapat ditemukan dan dapat dimakan di Indonesia adalah L. tuberregium dan L. badius yang dikonsumsi oleh masyarakat Papua

*Penulis korespondensi. Phone/Fax: +62-251-8622833, E-mail: lisdar.sudirman@yahoo.co.id
Barat (Sudirman 2005). Lentinus dapat dimakan karena dilaporkan mengandung nutrisi yang baik seperti karbohidrat, protein, lemak, mineral mikro dan makro, vitamin dan serat (Gulati et al. 2011). Lentinus ternyata juga memiliki potensi sebagai senyawa antimikrob (Sudirman 2005), antioksidan dan antiulcer (Omar et al. 2011), selain itu juga berpotensi untuk dibudidayakan (Karunarathna et al. 2011).

Jamur dapat dibudidayakan dengan menggunakan limbah biomassa lignoselulosa seperti jerami padi, jerami gandum, sekam biji kapas, ampas tebu, tongkol jagung, serbuk gergajian kayu, tandan kosong kelapa sawit (TKKS) dan limbah kertas, bergantung masing-masing jenis jamur. Limbah tersebut dapat menjadi media budi daya karena mengandung selulosa dan hemiselulosa sebagai sumber karbon (nutrisi utama) yang dibutuhkan jamur untuk tumbuh. Jerami padi merupakan media utama budi daya jamur di Nepal (Sharma et al. 2013), sedangkan serbuk gergajian kayu sengon adalah media budi daya 
jamur kayu yang umum digunakan di Indonesia. Seiring dengan semakin tinggi penggunaan serbuk gergajian kayu, maka ketersediaan media perlu diantisipasi dengan mencari alternatif media budi daya selain serbuk gergajian kayu, di antaranya TKKS yang keberadaannya melimpah di Indonesia. Salah satu jenis Lentinus yaitu L. cladopus berhasil dibudidayakan pada serbuk gergajian kayu karet dan TKKS di Malaysia (Leong \& Fauzi 1996).

Indonesia merupakan negara penghasil minyak sawit terbesar di dunia. Luas lahan perkebunan sawit tahun 2012 mencapai 9.23 juta ha. Industri pengolahan minyak sawit selain menghasilkan produk utama berupa minyak sawit, juga menghasilkan produk sampingan berupa biji inti sawit (kernel), limbah gas dan fraksional, limbah cair (minyak dan air) dan limbah padat (abu, cangkang, serat dan TKKS). Produk sampingan yang dihasilkan pabrik kelapa sawit pada tahun 2004 sebesar 12.365 juta ton TKKS, 10.215 juta ton cangkang dan serat, serta 37.633 juta ton limbah cair (palm oil mill effluent) (Sarwono 2008). TKKS merupakan limbah padat terbesar yang dihasilkan yaitu sekitar 23\% dari tandan buah segar sehingga dalam 1 ton kelapa sawit diperkirakan terdapat 230-250 kg TKKS dan dalam 1 juta ton tandan buah segar dihasilkan sekitar 230.000 ton TKKS (Fauzi 2005) dan jumlah ini akan terus meningkat seiring meningkatnya produksi tandan buah segar di Indonesia. Jutaan ton limbah TKKS tersebut belum dimanfaatkan secara optimal bahkan sering dibuang dan dibakar sehingga mencemari lingkungan dan menimbulkan polusi udara. Oleh karena itu, perlu dilakukan usaha pemanfaatan limbah lignoselulosa (TKKS) sebagai media budi daya jamur.

Pemanfaatan TKKS sebagai media produksi tubuh buah jamur telah dilakukan oleh beberapa peneliti di antaranya Endrawanto dan Suwadji (2000), Tabi et al. (2008), Sudirman et al. (2011), Ali et al. (2013), Kavitha et al. (2013) dan Harith et al. (2014). Sudirman et al. (2011) melaporkan bahwa TKKS dapat dijadikan media budi daya jamur Pleurotus isolat $\mathrm{F}$ dengan efisiensi biologi (EB) mencapai $152 \%$, sama halnya dengan Ganoderma isolat GKSA yang mampu menggunakan TKKS sebagai media produksi tubuh buah jamur dan dapat menurunkan rasio $\mathrm{C} / \mathrm{N}$ hingga $84 \%$ pada fase vegetatif dan lignin hingga $66 \%$ pada fase reproduktif. Harith et al.(2014) menggunakan beberapa limbah pertanian sebagai media produksi tubuh buah jamur Flammulina velutipes di antaranya tandan kosong kelapa sawit (EFB), serbuk gergajian kayu karet (SD), jerami padi (PS) dan sabut kelapa sawit tertekan (PPF). Hasil terbaik ditunjukkan oleh media campuran PS dan
EFB (25:75), PS dan PPF (50:50) serta PPF (100) dengan EB masing-masing $185.09 \%, 150.89 \%$ dan $129.06 \%$. Ali et al. (2013) mendapatkan EB yang lebih tinggi hingga mencapai $232.5 \%$ dan $138 \%$ untuk jamur Pleurotus ostreatus yang ditumbuhkan masing-masing pada media campuran PPF dan SD (50:50) serta EFB dan SD (50:50).

Penelitian ini bertujuan untuk mengetahui pertumbuhan dan produksi jamur Lentinus sajorcaju isolat LSC9 pada media serbuk gergajian kayu sengon (SGS), tandan kosong kelapa sawit (TKKS) dan campurannya. TKKS diharapkan dapat menjadi media alternatif untuk budi daya jamur isolat LSC9 selain SGS.

\section{BAHAN DAN METODE}

Isolat. Isolat jamur yang digunakan adalah Lentinus sajor-caju isolat LSC9, koleksi Prof Dr Lisdar I. Sudirman, Pusat Penelitian Sumberdaya Hayati dan Bioteknologi (PPSHB) IPB.

Peremajaan Isolat. Isolat LSC9 diremajakan pada media malt extract peptone (MEP) (ekstrak malt $15 \mathrm{~g}$, pepton $5 \mathrm{~g}$, glukosa $20 \mathrm{~g}$, agar-agar 15 g, akuades 1 L) di dalam cawan Petri berdiameter 9 $\mathrm{cm}$, kemudian diinkubasi pada suhu $35^{\circ} \mathrm{C}$ di dalam inkubator hingga miselium memenuhi cawan Petri.

Pembuatan Bibit Jamur. Bibit jamur isolat LSC9 dibuat dengan menggunakan pipilan jagung. Pipilan jagung direbus dengan air leding hingga lunak kemudian dimasukkan ke dalam botol volume 250 $\mathrm{mL}$ dan disterilisasi menggunakan autoklaf (suhu 121 ${ }^{\circ} \mathrm{C}$, tekanan 1.5 bar) selama 20 menit. Pipilan jagung yang telah steril diinokulasi dengan isolat LSC9 dan diinkubasi pada suhu $35^{\circ} \mathrm{C}$ di dalam inkubator hingga seluruh media dipenuhi miselium jamur.

Produksi Tubuh Buah. Isolat LSC9 dibudidayakan pada media serbuk gergajian kayu sengon (SGS), tandan kosong kelapa sawit (TKKS) dan campuran kedua media tersebut (C) dengan perbandingan masing-masing $1: 1$. Khusus untuk TKKS, sebelum digunakan terlebih dahulu dicacah hingga berbentuk serabut kasar kemudian digiling dengan mesin penggiling menjadi serabut yang lebih kecil dengan diameter sekitar $2 \mathrm{~cm}$. Serabut tersebut direndam semalam dengan air leding kemudian dicuci hingga bersih dan ditiriskan dalam karung dengan cara digantung sekitar 4 jam. Sedangkan SGS tidak diperlukan preparasi sampel terlebih dahulu. Selanjutnya, pada setiap jenis media (SGS, TKKS dan C) ditambahkan 15\% dedak padi, 1.5\% gipsum dan $1.5 \%$ kapur $\left(\mathrm{CaCO}_{3}\right)$, kemudian diberi air leding hingga kadar airnya mencapai 70-75\%. Setiap media dimasukkan ke dalam kantong plastik 
sebanyak $500 \mathrm{~g} / \mathrm{kantong}$ dan dibuat 10 kali ulangan sehingga total keseluruhannya berjumlah 30 kantong plastik. Kantong plastik berisi media disterilisasi menggunakan autoklaf (suhu $121{ }^{\circ} \mathrm{C}$, tekanan 1.5 bar) selama 30 menit kemudian didinginkan pada suhu ruang dan diinokulasi dengan bibit jamur isolat LSC9 sebanyak 2 sendok teh/kantong secara aseptik. Kantong plastik berisi bibit jamur diinkubasi di rumah jamur pada suhu $28-30{ }^{\circ} \mathrm{C}$. Parameter budi daya yang diamati adalah bobot basah tubuh buah (BB), efisiensi biologi (EB), laju produktivitas (LP), jumlah tudung jamur (JT), diameter tudung jamur (DT), fase vegetatif (FV), fase generatif (FG), masa pertumbuhan dan perkembangan (MPP). Fase vegetatif adalah fase yang dimulai sejak awal inokulasi bibit jamur hingga miselium memenuhi seluruh permukaan media, sedangkan FG dimulai pada saat kantong plastik dibuka sampai akhir panen yang ditandai dengan tidak muncul kembali tubuh buah dan mengempisnya kantong media. Masa pertumbuhan dan perkembangan adalah total fase vegetatif dan generatif. Laju produktivitas dihitung berdasarkan rataan total BB dibagi MPP (Sudirman 2014, komunikasi pribadi). Efisiensi biologi ditentukan dengan rumus: $\mathrm{EB}=($ bobot basah tubuh buah/bobot basah media x 100\%) x 4 (Stamets 1993).

Analisis Data. Hasil penelitian ditampilkan sebagai rata-rata \pm standard error mean (SEM) dari 10 kali ulangan. Data dianalisis menggunakan analyses of variance (ANOVA) dan diuji lanjut dengan Duncan's Multiple Range Test (DMRT) menggunakan program Microsoft Excel 2010 dan SPSS Statistics 21.0.

\section{HASIL}

Peremajaan Isolat. Miselium isolat LSC9 yang diremajakan pada media MEP berwarna putih. Miselium tersebut memerlukan waktu inkubasi lebih dari 7 hari untuk memenuhi cawan Petri (Gambar 1).



Gambar 1. Biakan Lentinus sajor-caju isolat LSC9 pada media MEP dengan masa inkubasi 7 hari, suhu $35^{\circ} \mathrm{C}$.
Produksi Tubuh Buah. Calon tubuh buah (primordium) isolat LSC9 berbentuk bulat berwarna krem dengan sedikit warna cokelat muda di bagian ujungnya serta dilengkapi dengan annulus (cincin) palsu ketika muncul ke permukaan media. Beberapa hari kemudian, primordium tersebut tumbuh menjadi tubuh buah dewasa. Tubuh buah isolat LSC9 berwarna coklat krem seperti daun kering, beraroma seperti kayu, berukuran relatif besar, tepi tudung jamur tidak beraturan (bergelombang) dengan tekstur yang licin dan liat, bagian tengah tudung jamur melengkung ke bawah (depressed), tangkai sangat pendek berukuran $1.58-1.7 \mathrm{~cm}$, posisi tangkai tidak berada di tengah (eksentrik) dan dalam 1 tangkai hanya terdapat 1 tudung jamur, lamela rapat dan turun mencapai tangkai (decurrent), memiliki annulus (cincin) palsu dan jejak spora berwarna putih (Gambar 2).

Berdasarkan hasil penelitian, isolat LSC9 dapat tumbuh dan memproduksi tubuh buah pada semua media yaitu SGS, TKKS dan C, namun secara umum media SGS merupakan media terbaik untuk pertumbuhan dan produksi tubuh buah isolat LSC9. Bobot basah isolat LSC9 pada semua media berkisar 36.88-63.60 g/kantong dengan rataan BB pada media SGS lebih tinggi dan berbeda nyata secara statistik terhadap kedua media lainnya dengan nilai $63.60 \mathrm{~g} /$ kantong dari 6 kali panen, sedangkan rataan BB pada media TKKS dan C masing-masing $43.02 \mathrm{~g} / \mathrm{kantong}$ dan $36.88 \mathrm{~g} /$ kantong dari 3-4 kali panen. Hasil yang sama ditunjukkan pada EB dan LP. Efisiensi biologi tertinggi ditunjukkan pada media SGS dengan nilai

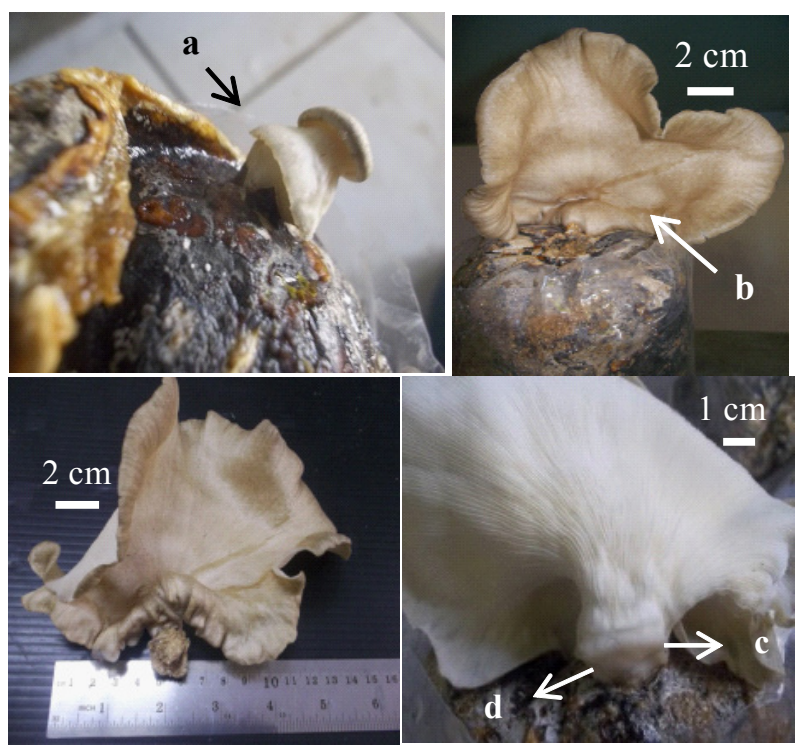

Gambar 2. Tubuh buah jamur Lentinus sajor-caju isolat LSC9 pada media serbuk gergajian kayu sengon (SGS), a: primordium dengan annulus (cincin) palsu, b: tubuh buah dewasa, c: annulus (cincin) palsu, d: tangkai jamur. 
$50.88 \%$ dan berbeda nyata secara statistik terhadap kedua media lainnya, sedangkan EB pada semua media yang diamati 29.51-50.88\% (Gambar 3). Laju produksi isolat LSC9 pada media SGS juga lebih tinggi dari media TKKS dan $\mathrm{C}$ dengan nilai masing-masing $0.43 \mathrm{~g} / \mathrm{hari}, 0.38 \mathrm{~g} /$ hari dan $0.26 \mathrm{~g} /$ hari dan secara statistik LP pada media SGS dan TKKS berbeda nyata terhadap media C (Gambar 4).

Kisaran fase vegetatif, FG dan MPP pada semua media masing-masing 16-23 hari, 100-129 hari dan 115-148 hari dengan FV, FG dan MPP terpendek pada media TKKS dengan rataan berturut-turut 16 , 100 dan 115 hari (Gambar 5).

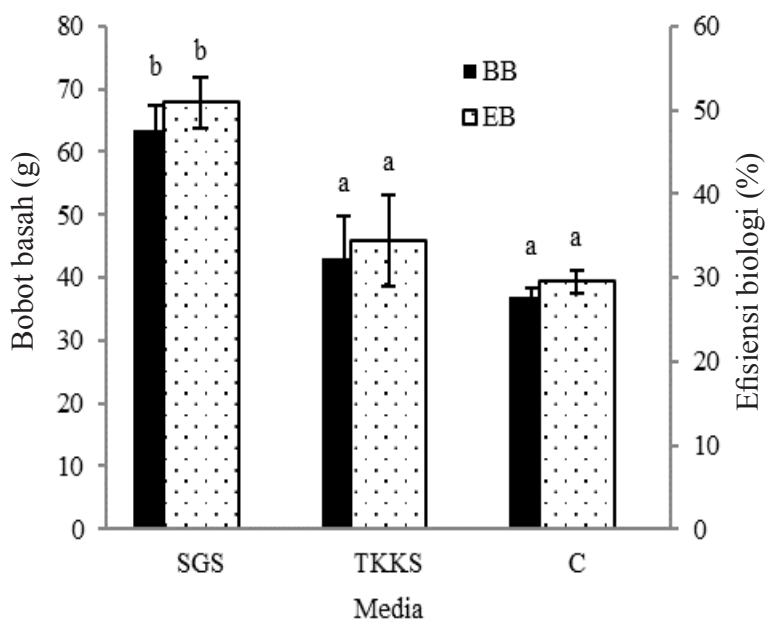

Gambar 3. Bobot basah tubuh buah dan efisiensi biologi Lentinus sajor-caju isolat LSC9 pada 3 jenis media. SGS: serbuk gergajian kayu sengon (Paraserianthes falcataria), TKKS: tandan kosong kelapa sawit, C: campuran media SGS dan TKKS $(1: 1)$. Huruf yang berbeda pada gambar yang sama menunjukkan perbedaan yang nyata $(\mathrm{p}<0.05)$

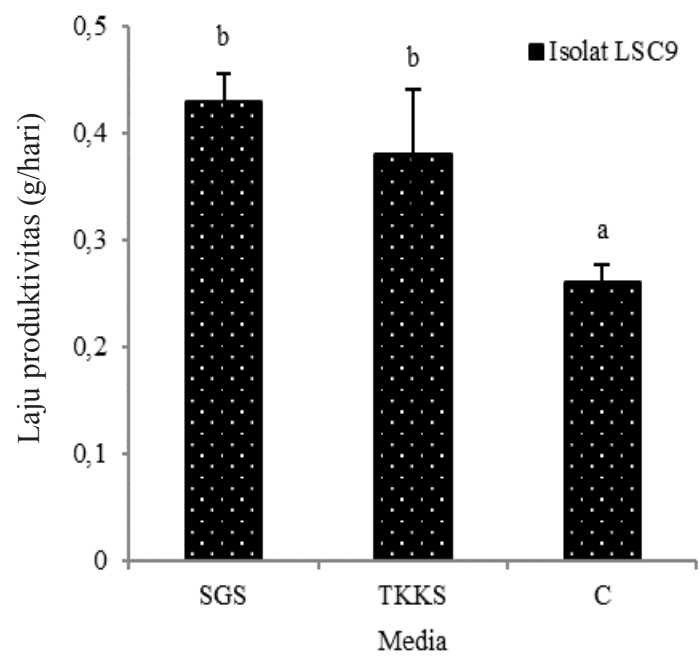

Gambar 4. Rataan laju produktivitas Lentinus sajor-caju isolat LSC9 pada 3 jenis media. SGS: serbuk gergajian kayu sengon (Paraserianthes falcataria), TKKS: tandan kosong kelapa sawit, C: campuran media SGS dan TKKS (1:1). Huruf yang berbeda pada gambar menunjukkan perbedaan yang nyata $(\mathrm{p}<0.05)$
Jumlah tudung jamur pada media SGS lebih banyak dan berbeda nyata secara statistik dari kedua media lainnya yaitu 12 buah/kantong, sedangkan JT pada semua media berkisar antara 5-12 buah/ kantong. Diameter tudung jamur pada ketiga media tidak menunjukkan perbedaan yang nyata $(\mathrm{p}>0.05)$ dengan kisaran 8.35-10.17 cm. Isolat LSC9 memiliki rataan DT tertinggi pada media $\mathrm{C}$ dengan nilai 10.17 cm (Gambar 6).

\section{PEMBAHASAN}

Miselium isolat LSC9 memenuhi cawan Petri pada masa inkubasi 10 hari. Laju pertumbuhan

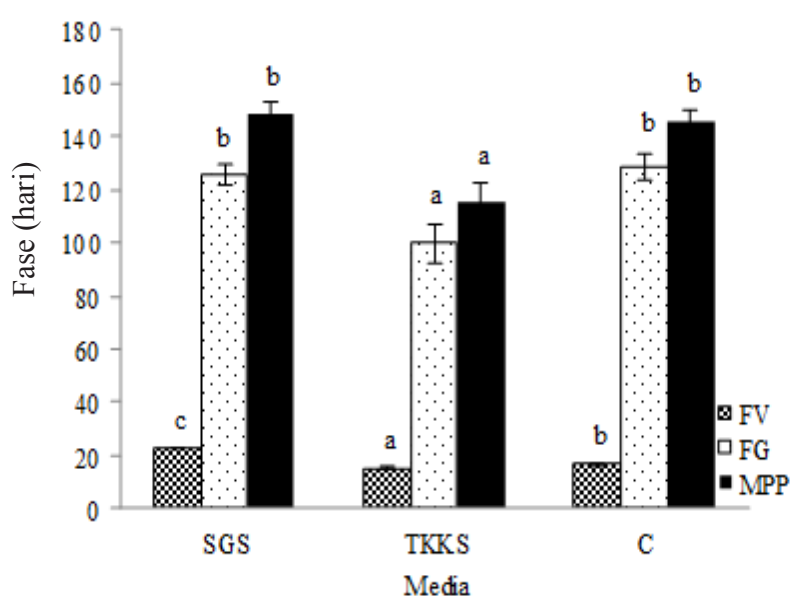

Gambar 5. Fase pertumbuhan Lentinus sajor-caju isolat LSC9 pada 3 jenis media. SGS: serbuk gergajian kayu sengon (Paraserianthes falcataria), TKKS: tandan kosong kelapa sawit, C: campuran media SGS dan TKKS (1:1), FV: fase vegetatif, FG: fase generatif, MPP: masa pertumbuhan dan perkembangan. Huruf yang berbeda pada gambar yang sama menunjukkan perbedaan yang nyata $(\mathrm{p}<0.05)$

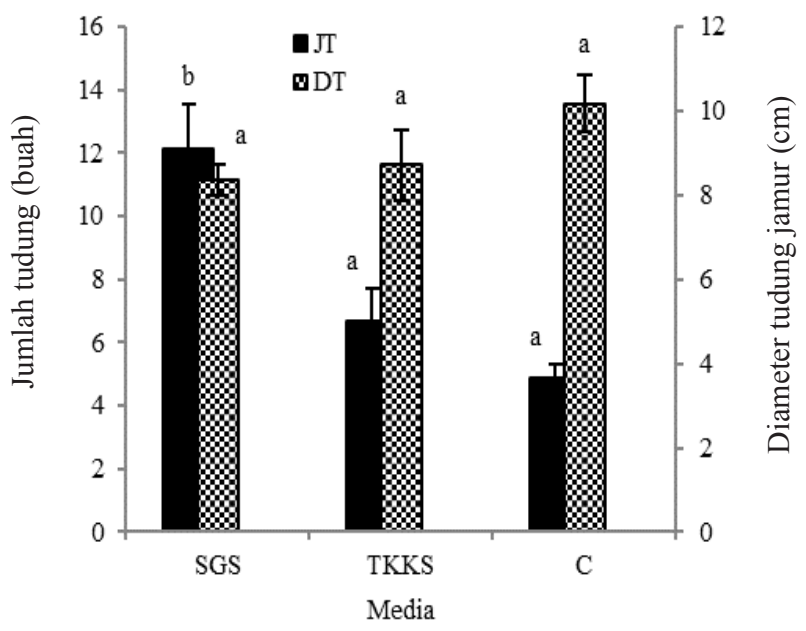

Gambar 6. Rataan jumlah tudung dan rataan diameter tudung Lentinus sajor-caju isolat LSC9 pada 3 jenis media. SGS: serbuk gergajian kayu sengon (Paraserianthes falacataria), TKKS: tandan kosong kelapa sawit, C: campuran media SGS dan TKKS (1:1). Huruf yang berbeda pada gambar yang sama menunjukkan perbedaan yang nyata $(\mathrm{p}<0.05)$ 
miselium isolat LSC9 pada media MEP dengan suhu inkubasi $35{ }^{\circ} \mathrm{C}$ adalah $0.84 \mathrm{~cm} /$ hari, lebih lambat dari LPM beberapa isolat Lentinus lainnya seperti isolat LPM, LSC, LPT, LP, LU, LCEL dan LC yang ditumbuhkan pada media yang sama pada suhu 36 ${ }^{\circ} \mathrm{C}$ dengan kisaran 1.74-2.08 cm/hari (Yunilda, tidak dipublikasikan).

Media budi daya yang dipenuhi miselium berwarna putih terlihat berubah menjadi warna hitam dan mengeras pada akhir fase vegetatif. Setelah itu, primordium pertama akan muncul. Waktu yang dibutuhkan jamur untuk membentuk primordium pertama setelah kantong plastik dibuka adalah 3-4 hari sebelum panen pertama. Panen pertama pada semua media memerlukan waktu 41-73 hari setelah akhir FV. Media serbuk gergajian kayu sengon menunjukkan waktu panen pertama tercepat dengan 41 hari, sedangkan media $\mathrm{C}$ membutuhkan waktu paling lama yaitu 73 hari.

Berdasarkan hasil penelitian ini, media SGS merupakan media terbaik untuk pertumbuhan dan produksi tubuh buah isolat LSC9 dibandingkan media TKKS dan C dengan EB mencapai 50.88\%. Serbuk gergajian kayu sengon merupakan media yang umum digunakan untuk budi daya jamur kayu di Indonesia. Media SGS mengandung selulosa yang lebih tinggi (48.3\%) dari TKKS (36\%) (Sudirman et al. 2011), namun memiliki kandungan hemiselulosa yang lebih rendah (24.59\%) dari TKKS (34\%) (Anggraini \& Roliadi 2011). Pada penelitian ini, panen dilakukan saat tudung jamur sudah mekar sempurna, akan tetapi jamur Lentinus sajor-caju ternyata dikonsumsi oleh masyarakat pada waktu masih muda (Abdullah \& Rusea 2009), karena tubuh buah dewasa keras dan liat. Oleh karena itu, jika tubuh buah jamur masih muda ini dipanen maka EB yang dihasilkan dapat lebih rendah dari EB pada penelitian ini.

Efisiensi biologi isolat LSC9 pada media SGS lebih tinggi bila dibandingkan EB pada beberapa jenis Lentinus yang ditumbuhkan pada berbagai media seperti L. squarrosulus pada media serbuk gergajian kayu Mansonia altissima (4.27\%) (Ayodele et al. 2007), L. cladopus yang dibudidayakan pada media campuran jerami gandum dan jerami padi (33.35\%) (Atri \& Lata 2013), L. squarrosulus yang ditumbuhkan pada kayu Spondias mombin (10.25\%) (Adesiana et al. 2011) dan serbuk gergajian kayu Brachystegia nigerica (5.44\%) (Okhuoya et al. 2005).

Efisiensi biologi isolat LSC9 pada semua media jauh lebih rendah dari EB Pleurotus isolat F (152$167 \%$ ) yang ditumbuhkan pada 3 jenis media yang sama yaitu SGS, TKKS dan C (Sudirman et al. 2011).
Akan tetapi, kedua isolat tersebut ternyata mampu tumbuh lebih cepat pada media TKKS dengan masa pertumbuhan dan perkembangan yang tidak jauh berbeda, masing-masing 115 hari (isolat LSC9) dan 111 hari (Pleurotus isolat F).

Media yang menghasilkan jumlah tudung jamur paling banyak adalah SGS, tetapi diameter tudung jamur paling kecil, sedangkan jumlah tudung jamur paling sedikit pada media $\mathrm{C}$, tetapi diameter tudung jamur paling besar di antara kedua media lainnya. Hal itu menunjukkan bahwa penggunaan media budi daya yang berbeda dapat menghasilkan jamur dengan ukuran diameter tudung yang berbeda pula. Hal ini didukung oleh laporan Jonathan et al. (2013) yang telah membudidayakan Pleurotus pulmonarius pada 4 jenis media yang berbeda. Diameter tudung P. pulmonarius terbesar dihasilkan media jerami gandum $(8.86 \mathrm{~cm})$, sedangkan diameter tudung jamur pada media serat sabut kelapa, serbuk gergajian kayu jati putih (Gmelina arborea) dan limbah kelapa sawit berturut-turut adalah 8.46, 6.78 dan $5.18 \mathrm{~cm}$. Demikian pula laporan dari Islam et al. (2009) bahwa P. flabellatus menghasilkan diameter tudung jamur yang berbeda-beda pada berbagai macam media budi daya. Pleurotus flabellatus pada media serbuk gergajian kayu mangga (Mangifera indica) menunjukkan diameter tudung jamur terbesar (7 $\mathrm{cm}$ ), sedangkan $P$. flabellatus pada media yang lain yaitu serbuk gergajian kayu nangka (Artocarpus heterophyllus), kelapa (Cocos nucifera), jambu (Syzygium spp.), mahoni (Swietonia macrophylla), shiris (Albizzia spp.) dan kadom (Anthocephalus sinensis) menghasilkan tudung jamur yang lebih rendah dengan kisaran 4-6.9 cm. Menurut Sudirman et al. (2011), JT dan DT yang dihasilkan tergantung pada teknik membuka kantong plastik setelah miselium memenuhi seluruh permukaan media. Semakin luas daerah yang dibuka maka JT yang terbentuk akan semakin banyak, namun DT akan semakin kecil. Yildiz et al. (2002) menambahkan bahwa DT yang dihasilkan juga bergantung pencahayaan. Jika jamur tumbuh pada kondisi pencahayaan yang kurang, maka DT yang dihasilkan kecil, tangkai jamur panjang dan hasil panen cenderung rendah.

Media TKKS dapat dijadikan sebagai media alternatif untuk produksi tubuh buah Lentinus sajor-caju isolat LSC9 meskipun tidak lebih baik dari media SGS. Pengontrolan faktor lingkungan, pengomposan media budi daya atau penambahan suplemen dibutuhkan pada penelitian selanjutnya untuk mendapatkan hasil panen dan produksi tubuh buah yang lebih tinggi. 


\section{UCAPAN TERIMA KASIH}

Penulis mengucapkan terima kasih kepada Lembaga Pengelola Dana Pendidikan (LPDP) yang telah memberikan dukungan finansial melalui program beasiswa Tesis Dalam Negeri Tahap VII tahun 2013. Penulis juga mengucapkan terima kasih kepada rekan-rekan yang telah membantu dalam penelitian ini: Pak Iwa, Pak Engkus, Pak Kusnadi, Alhidayatullah dan Hamtini Yamin.

\section{REFERENSI}

Abdullah F, Rusea G. 2009. Documentation of inherited knowledge on wild edible fungi from Malaysia. Blumea 54:35-38.

Adesina, Felicia C, Fasidi IO, Adenipekun OC. 2011. Cultivation and fruit body production of Lentinus squarrosulus Mont. (Singer) on bark and leaves of fruit trees supplemented with agricultural waste. Afr J Biotechnol 10:4608-4611.

Ali N, Tabi ANM, Zakil FA, Fauzai WNFM, Hassan O. 2013. Yield performance and biological efficiency of empty fruit bunch (EFB) and palm pressed fibre (PPF) as substrates for the cultivation of Pleurotus ostreatus. Jurnal Teknologi 64:93-99.

Anggraini D, Roliadi H. 2011. Pembuatan pulp dari tandan kosong kelapa sawit untuk karton pada skala usaha kecil. JPHH 29:211-225.

Atri NS, Lata. 2013. Studies for culturing and cultivation of Lentinus cladopus Lev. Mycosphere 4:675-682.

Ayodele SM, Akpaja EO, Anyiador F. 2007. Evaluation of the yield of Lentinus squarrosulus (Mont) Singer on selected economic tress species. Pak J Biol Sci 10:4283-4286.

Endrawanto, Suwadji E. 2000. Kultivasi jamur kuping (Auricularia sp.) dalam media tandan kosong kelapa sawit dan serbuk gergaji hasil iradiasi. Risalah Pertemuan Ilmiah Penelitian dan Pengembangan Teknologi Isotop dan Radiasi XII, BATAN, Jakarta 23-24 Februari 2000. Badan Tenaga Nuklir Nasional. hlm 169-173.

Fauzi Y. 2005. Kelapa Sawit, Budi Daya Pemanfaatan Hasil dan Limbah, Analisis Usaha dan Pemasaran. Jakarta: Penebar Swadaya.

Gbolagade J, Ajayi A, Oku A, Wankasi D. 2006. Nutritive value of common wild edible mushrooms from Southern Nigeria. Global J Biotech \& Biochem 1:16-21.

Gulati A, Atri NS, Sharma AK, Sharma BM. 2011. Nutritional studies on five wild Lentinus species from North-West India. World J Dairy \& Food Sci 6:140-145.

Harith N, Abdullah N, Sabaratnam V. 2014. Cultivation of Flammulina velutipes mushroom using various agro-residues as a fruiting substrate. Pesq Agropec Bras 49:181-188.

Islam MZ, Rahman MH, Hafiz F. 2009. Cultivation of oyster mushroom (Pleurotus flabellatus) on different substrates. Int J Sustain Crop Prod 4:45-48.

Jonathan SG, Nwokolo VM, Ekpo EN. 2013. Yield performance of Pleurotus pulmonarius (Fries.) quelet, cultivated on different agro-forest wastes in Nigeria. World Rural Observ 5:22-30.
Karunarathna SC, Yang ZL, Zhao RL, Vellinga EC, Bahkali AH, Chukeatirote E, Hyde KD. 2011. Three new species of Lentinus from Northern Thailand. Mycol Prog 10:389-398.

Kavitha B, Rajannan G, Jothimani P. 2013. Utilization of empty fruit bunch of oil palm as alternate substrate for the cultivation of mushroom. IJSET 2:839-846.

Kumar M, Kaviyarasan V. 2012. Distribution of Lentinus tuberregium (Fr.), an indigenous edible medicinal mushroom in Tamil Nadu, South India. J Acad Indus Res 1:296-300.

Leong CM, Fauzi D. 1996. Penanaman dan penentuan komposisi proksimat dalam cendawan Lentinus cladopus. Proceeding of 4th Symposium of Applied Biology, Bangi, Selangor, Malaysia 28-29 Mei 1996. Malaysian Applied Biology Society. p 79-81.

Okhuoya JA. Akpaja EO, Oghenekaro A. 2005. Cultivation of Lentinus squarrosulus (Mont.) Singer on sawdust of selected tropical tree species. Int J Med Mushrooms 7:440-441.

Okhuoya JA, Akpaja EO, Osemwegie OO, Oghenekaro AO, Ihayere CA. 2010. Nigerian mushrooms: underutilized nonwoodforest resources. J Appl Sci Environ Manag 14:43-54.

Omar NAM, Abdullah N, Kuppusamy UR, Abdulla MA, Sabaratnam V. 2011. Nutritional composition, antioxidant activities, and antiulcer potential of Lentinus squarrosulus (Mont.) mycelia extract. eCAM 2011:1-8.

Rattanamalee S, Rattanamalee C. 2012. The biology of Lentinus polychrous Lev. in Nakhon Phanom Province, Thailand and Kwaeng Kham Muan, Laos. IJERD 3:121-126.

Sarwono E. 2008. Pemanfaatan janjang kosong sebagai substitusi pupuk tanaman kelapa sawit. Jurnal Aplika 8:19-23.

Sharma S, Yadav RKP, Pokhrel CP. 2013. Growth and yield of oyster mushroom (Pleurotus ostreatus) on different substrates. JNBR 2:3-8.

Stamets P. 1993. Growing Gourmet and Medicinal Mushrooms. Hongkong: Ten Speed Press and Mycomedia.

Sudirman LI. 2005. Deteksi senyawa antimikrob yang diisolasi dari beberapa Lentinus tropis dengan metode bioautografi. Hayati 12:67-72.

Sudirman LI, Sutrisna A, Listiyowati S, Fadli L, Tarigan B. 2011. The potency of oil palm plantation wastes for mushroom production. Proceedings of the $7^{\text {th }}$ International Conference on Mushroom Biology and Mushroom Products (ICMBMP7), Arcachon, France 4-7 Oktober 2011. JM Savoie, MF Oriol, M Largeteau, G Barroso (Editor). World Society for Mushroom Biology and Mushroom Products (WSMBMP). p 378-384.

Tabi ANM, Zakil FA, Fauzai WNFM, Ali N, Hassan O. 2008. The usage of empty fruit bunch (EFB) and palm pressed fibre (PPF) as substrates for the cultivation of Pleurotus ostreatus. Jurnal Teknologi 49:186-196.

Yildiz S, Yildiz UC, Gezer ED, Temiz A. 2002. Some lignocellulosic wastes used as raw material in cultivation of the Pleurotus ostreatus culture mushrooom. Process Biochem 38:301-306.

Yoon KN, Alam N, Lee KR, Shin PG, Cheong JC, Yoo YB, Lee TS. 2011. Antioxidant and antityrosinase activities of various extracts from the fruiting bodies of Lentinus lepideus. Molecules 16:2334-2347. 